\title{
HUBUNGAN PENGETAHUAN, SIKAP DAN PERSEPSI IBU DENGAN STATUS IMUNISASI DASAR DI WONOKUSUMO
}

\section{CORRELATION OF KNOWLEDGE, ATTITUDE AND MOTHER PERCEPTION WITH BASIC IMMUNIZATION STATUS IN WONOKUSUMO}

Tri Anisca Dillyana1), Ira Nurmala2)

\footnotetext{
${ }^{1}$ Departemen Promosi Kesehatan dan Ilmu Perilaku, Fakultas Kesehatan Masyarakat, Universitas Airlangga Surabaya

2 Departemen Promosi Kesehatan dan Ilmu Perilaku, Fakultas Kesehatan Masyarakat, Universitas Airlangga Surabaya

E-mail: tri.anisca.dillyana-2016@fkm.unair.ac.id
}

\begin{abstract}
Background: Basic immunization is the first immunization that should be given to everyone, especially infants and children from birth to protect lifes from dangerous diseases. The immunization program in Indonesia requires every infant (0-11 months) to receive complete basic immunization consist of 1 dose of Hepatitis B, 1 dose of BCG, 3 doses of DPT-HB-Hib, 4 doses of polio, and 1 dose of measles. Basic Immunization in RW 8 Wonokusumo Urban Village in 2017 has not reached the target. Only 73 infants (67\%) of 108 have received complete basic immunization which the target of Puskesmas is $95 \%$. This study aims to know the correlation of knowledge, attitude and mother perception with the basic immunization status in Wonokusumo. This study is an observational analytic research with quantitative approach. The study was cross sectional with a sample of 39 respondents. The sampling technique used is purposive sampling. Respondents in this study are mothers who have children under three and have KMS in RW 8 Wonokusumo Urban Village. Primary data collection techniques obtained from questionnaires while secondary data obtained from Wonokusumo Puskesmas and Surabaya City Health Office reports. The result of bivariate statistic test shows that there is correlation between knowledge, attitude, and mother perception with the immunization status of children under three with $p=0.001(p<0.05)$. Conclusion: There is correlation between knowledge, attitude, and mother perception with the basic immunization status in RW 8, Wonokusumo Village.
\end{abstract}

Keywords: knowledge, attitude, perception, basic immunization status

\begin{abstract}
ABSTRAK
Latar Belakang: Imunisasi dasar merupakan imunisasi yang wajib diberikan pada bayi dan anak sejak lahir agar tubuhnya terlindung dari penyakit-penyakit yang berbahaya. Program imunisasi di Indonesia mewajibkan imunisasi dasar lengkap bagi setiap bayi (usia 0-11 bulan) yang terdiri dari 1 dosis Hepatitis B, 1 dosis BCG, 3 dosis DPT-HB-Hib, 4 dosis polio, dan 1 dosis campak. Imunisasi dasar lengkap di RW VIII Kelurahan Wonokusumo pada tahun 2017 belum mencapai target yaitu dari 108 hanya 73 bayi $(67,6 \%)$ yang telah mendapatkan imunisasi dasar lengkap, dimana target Puskesmas adalah 95\%. Tujuan: Tujuan penelitian untuk mengetahui hubungan pengetahuan, sikap, dan persepsi ibu dengan status imunisasi dasar di Wonokusumo. Metode: Penelitian ini merupakan penelitian observasional analitik dengan pendekatan kuantitatif. Penelitian ini termasuk cross sectional dengan sampel 39 responden. Teknik sampling yang digunakan adalah purposive sampling. Responden dalam penelitian ini yaitu ibu yang memiliki batita dan memiliki KMS di RW 8 Kelurahan Wonokusumo. Teknik pengumpulan data primer diperoleh dari kuesioner sedangkan data sekunder diperoleh dari laporan Puskemas Wonokusumo dan Dinas Kesehatan Kota Surabaya. Hasil: Hasil penelitian uji statistik bivariat menunjukkan terdapat hubungan pengetahuan, sikap, dan persepsi ibu
\end{abstract}


dengan status imunisasi batita dengan $p=0,001(p<0,05)$. Kesimpulan: Terdapat hubungan antara pengetahuan, sikap, dan persepsi ibu dengan status imunisasi dasar di RW 8 Kelurahan Wonokusumo.

Kata Kunci: pengetahuan, sikap, persepsi, status imunisasi dasar

\section{PENDAHULUAN}

Kesehatan merupakan salah satu hal yang penting dalam kehidupan. Setiap orang menginginkan dirinya selalu sehat, sehingga bisa hidup secara mandiri dan produktif. Manusia yang sehat tidak hanya dilihat dari segi jasmani, tetapi juga sehat rohani. (Azwar, 2004; Wenjiong, 2011).

Menurut Keputusan Menteri Kesehatan Republik Indonesia Nomor 12 Tahun 2017 tentang Penyelenggaraan Imunisasi dijelaskan bahwa di Indonesia saat ini sedang menghadapi dua permasalahan kesehatan yang menjadi beban ganda (double burden) yakni terkait munculnya penyakit menular dan tidak menular (penyakit degeneratif). Penyakit menular sulit untuk diatasi atau diberantas karena penyebarannya tidak mengenal batas wilayah administrasi, sehingga perlu disediakan vaksin yang dapat mencegah penyakit menular tertentu.

Imunisasi merupakan salah satu intervensi kesehatan yang terbukti paling cost-effective (murah), karena dapat mencegah dan mengurangi kejadian kesakitan, kecacatan, dan kematian akibat PD3I yang diperkirakan 2 hingga 3 juta kematian tiap tahunnya. Kekebalan yang didapatkan seseorang melalui imunisasi merupakan kekebalan aktif, sehingga apabila terpapar suatu penyakit tertentu maka hanya akan mengalami sakit ringan dan tidak sampai sakit. Penyakit menular seperti TBC, Difteri, Tetanus, Hepatitis B, Pertusis, Campak, Polio, radang selaput otak, dan radang paru-paru merupakan beberapa penyakit yang termasuk ke dalam Penyakit yang Dapat Dicegah dengan Imunisasi (PD3I). Imunisasi akan memberikan perlindungan bagi anak terhadap penyakit berbahaya tersebut dan dapat mencegah kecacatan serta tidak akan menimbulkan kematian (Kemenkes, 2016).

Imunisasi dasar berhak diperoleh oleh setiap anak agar penyakit dapat dicegah dan dihindari dan imunisasi dasar lengkap wajib diberikan kepada setiap bayi dan anak oleh pemerintah tercantum dalam
Undang-Undang Kesehatan Nomor 36 Tahun 2009. Penyelenggaraan imunisasi tertuang dalam Peraturan Menteri Kesehatan Nomor 42 Tahun 2013.

Semua orang, terutama bayi dan anak wajib diberi imunisasi dasar sejak lahir untuk melindungi tubuhnya dari berbagai penyakit (Maryunami, 2010). Setiap bayi (usia 0-11 bulan) wajib mendapatkan imunisasi dasar lengkap yang terdiri dari Hepatitis B, BCG, DPT-HB-Hib, polio, dan campak. Awal mula terjadinya suatu penyakit berasal dari virus atau bakteri yang menyerang tubuh manusia. Benda asing yang masuk ke dalam tubuh dikategorikan sebagai agent yang tidak dikenal tubuh, sehingga sistem kekebalan tubuh akan membuat antibodi untuk menyerang antigen yang masuk ke dalam tubuh tersebut. Imunisasi salah satu langkah yang diberikan agar terbentuk sistem kekebalan tubuh terhadap paparan dari penyakit (Ranuh, et al., 2008).

Imunisasi yang dapat menimbulkan kekebalan aktif terhadap penyakit paru-paru yang sangat menular atau tuberkulosis (TBC) yaitu imunisasi BCG (Maryunani, 2010). Pemberian vaksin BCG (Bacille Calmette Guerrin) dilakukan satu kali pemberian pada anak usia 0-1 bulan. Efek samping BCG dimana terdapat benjolan merah selama seminggu setelah melakukan vaksinasi BCG. Imunisasi Hepatitis $B$ diberikan untuk melindungi tubuh dari infeksi hati pada anak-anak yang disebabkan oleh virus Hepatitis B. Imunisasi minimal diberikan sebanyak 3 kali. Pemberian pertama kali pada saat segera setelah lahir, selanjutnya diberikan lagi dengan jarak minimal 1 bulan dan yang ketiga merupakan booster yaitu pada usia 3 sampai 6 bulan (Depkes RI, 2006).

Imunisasi DPT dapat menimbulkan kekebalan aktif terhadap penyakit difteri, pertusis, dan tetanus. Penyakit difteri dapat menyebabkan kematian akibat tersumbatnya tenggorokan dan kerusakan jantung. Penyakit pertusis merupakan penyakit yang menyerang paru dan ditandai 
dengan batuk rejan selama 100 hari. Penyakit tetanus yaitu penyakit kejang otot yang terjadi pada seluruh tubuh disertai dengan mulut terkunci sehingga mulut tidak bisa membuka atau dibuka (Sudiarti, 2010).

Imunisasi polio dapat memberikan kekebalan terhadap penyakit poliomyelitis yaitu penyakit yang dapat mengakibatkan kelumpuhan pada kaki. Kandungan vaksin polio adalah virus yang dilemahkan. Pemberian vaksin polio melalui cara diteteskan secara oral sebanyak 4 kali, pertama kali dilakukan pada usia 0-1 bulan secara oral/ tetes. Imunisasi campak dapat menimbulkan kekebalan terhadap penyakit campak. Penyakit campak merupakan penyakit menular dan mudah menyerang pada anak-anak yang memiliki daya tahan tubuh lemah. (Depkes RI, 2006; Maryunani, 2010).

Keberhasilan program imunisasi dapat memberikan cakupan imunisasi yang tinggi dan memelihara imunitas yang ada di masyarakat, namun cakupan imunisasi dasar dipengaruhi oleh berbagai faktor, antara lain sikap petugas, lokasi imunisasi, kehadiran petugas, usia ibu, tingkat pendidikan ibu, tingkat pendapatan keluarga per bulan, kepercayaan terhadap dampak buruk pemberian imunisasi, status pekerjaan ibu, tradisi keluarga, tingkat pengetahuan ibu, dan dukungan keluarga (Bernsen, 2011; Rahmawati, 2014).

Kementerian Kesehatan RI menyatakan bahwa, capaian Imunisasi Dasar Lengkap (IDL) pada tahun 2016 sebesar 91,58\%. Capaian ini lebih besar dari capaian tahun 2015 sebesar 86,54\%. Angka ini mencapai target Renstra tahun 2016 sebesar 91,5\% (Kemenkes, 2016).

Cakupan imunisasi dasar lengkap di Jawa Timur yaitu cakupan Bayi Laki-Laki dan Perempuan yang di imunisasi DPT-HB3// DPT--HB-- Hiib3 sebanyak 553.848 bayi (97 \%) belum memenuhi target, bayi yang diimunisasi polio 4 sebanyak 544.529 bayi $(95,34 \%)$, diimunisasi campak sebanyak 556.307 bayi $(97,40 \%)$ sedangkan bayi yang telah diimunisasi dasar lengkap (IDL) berjumlah 561.744 bayi (98,36 \%). Target Imunisasi Dasar Lengkap (IDL) Provinsi Jawa Timur 2016 adalah 91,5\%, dari 38 Kabupaten/Kota yang IDLnya telah melampaui 91,5\% berjumlah 34 Kabupaten. Hal tersebut sudah dapat tercapai dengan keterangan yaitu pada imunisasi DPT-HB3/ DPT-HB-HIIB3 telah mencapai 97\% bayi laki-laki dan perempuan, selain itu untuk imunisasi Polio4 juga sudah mencapai $95,34 \%$, imunisasi campak sebesar 97,4\%, serta pencapaian imunisasi dasar lengkap telah mencapai 98,36\% (Dinas Kesehatan Provinsi Jawa Timur, 2016).

Cakupan imunisasi dasar lengkap di Kota Surabaya tahun 2016 sebesar 94,72 \% yang meliputi imunisasi Hepatitis < 7 hari sebesar $86,15 \%$, BCG sebesar $91,68 \%$, imunisasi DPT3+HB3 sebesar 91,70\%, imunisasi Polio 4 sebesar 91,27\%, dan imunisasi Campak sebesar 92,74\% (Dinas Kesehatan Kota Surabaya, 2016). Data dari Puskesmas Wonokusumo, diketahui bahwa hasil cakupan imunisasi bayi di wilayah Puskesmas Wonokusumo tahun 2016 belum memenuhi target, yaitu BCG sebesar 64,87\%, DPT1+HB1 sebesar 84,30\%, DPT3+HB3 sebesar 69,37\%, Polio 3 sebesar $69,4 \%$, dan campak sebesar $70,79 \%$.

Data Puskesmas Wonokusumo diketahui bahwa imunisasi dasar lengkap di RW VIII Kelurahan Wonokusumo pada tahun 2017 belum mencapai target, dari 108 hanya 73 bayi $(67,6 \%)$ yang telah mendapatkan imunisasi dasar lengkap dimana target Puskesmas Wonokusumo adalah 95\%. Faktor umur, tingkat pendidikan, pekerjaan, pengetahuan ibu, dan ketersediaan vaksin akan mempengaruhi kelengkapan imunisasi dasar (Elly, 2011; Widiyanti, 2008). Faktor lain yang berhubungan dengan kelengkapan imunisasi dasar antara lain dukungan keluarga, efek samping imunisasi, sikap petugas kesehatan, dan tempat pelayanan imunisasi (Kurniawati, 2012). Pengetahuan memiliki peranan penting terhadap seseorang untuk bertindak. Sikap merupakan suatu reaksi seseorang yang masih tertutup terhadap suatu rangsangan dimana faktor pendapat dan emosi sudah terlibat di dalamnya, jadi penggunaan pelayanan kesehatan dipengaruhi oleh sikap dan pengetahuan seseorang yang dapat memilih dan memutuskan dalam penggunaan pelayanan kesehatan (Notoatmodjo, 2010).

Peneliti memandang sangat penting untuk mengetahui pengetahuan, sikap, dan persepsi individu mengenai suatu masalah dan bagaimana individu tersebut mengaplikasikannya dalam perilaku pencegahan guna memaksimalkan upaya 
preventif dari peningkatan kejadian suatu penyakit yang mungkin terjadi pada balita. Tujuan dari penelitian ini adalah untuk mengidentifikasi hubungan pengetahuan, sikap, dan persepsi ibu dengan status imunisasi dasar batita di RW 8 Kelurahan Wonokusumo.

\section{METODE}

Penelitian ini termasuk dalam penelitian observasional karena dilakukan dengan mengamati subyek penelitian tanpa memberikan perlakuan tertentu. Variabel yang akan diteliti adalah pengetahuan, sikap, dan persepsi ibu tentang imunisasi dasar lengkap. Analisis data dilakukan secara analitik. Berdasarkan dimensi waktu, penelitian ini merupakan crosssectional dimana variabel penelitian diukur dalam suatu periode tertentu. Populasi penelitian ini adalah ibu yang memiliki batita dan memiliki KMS di RW 8 Kelurahan Wonokusumo yaitu sebanyak 108 orang. Pengambilan sampel menggunakan teknik Purposive Sampling dan diperoleh jumlah sampel sebanyak 39 ibu batita. Lokasi penelitian berada di RW 8 Kelurahan Wonokusumo yang dilaksanakan pada bulan Januari 2018.

Pengumpulan data primer menggunakan kuesioner yang diisi sendiri oleh responden. Kuesioner terdiri dari 40 pertanyaan meliputi 12 pertanyaan tentang pengetahuan, 12 pertanyaan tentang sikap, dan 16 pertanyaan tentang persepsi mengenai imunisasi dasar. Data akan diolah dengan editing, coding, scoring, transferring, dan tabulating yang selanjutnya dilakukan analisis menggunakan Chi-Square untuk melihat hubungan antar variabel dengan kemaknaan ditentukan berdasarkan nilai $p<0,05$. Pengumpulan data sekunder menggunakan data cakupan imunisasi dasar yang diperoleh dari laporan Puskesmas Wonokusumo dan Dinas Kesehatan Kota Surabaya.

\section{HASIL DAN PEMBAHASAN}

\section{Karakteristik Responden}

Karakteristik responden di RW 8 Kelurahan Wonokusumo meliputi umur, pendidikan, dan pekerjaan responden. Berdasarkan Tabel 1 diketahui bahwa jumlah responden berdasarkan umur yang paling banyak adalah umur 17-30 tahun yaitu sebesar $51,28 \%$ dan yang paling sedikit adalah umur 45-58 tahun yaitu sebesar 10,26\%. Hasil penelitian juga menunjukkan bahwa tingkat pendidikan paling banyak adalah tingkat pendidikan rendah sebanyak $50 \%$, sebagian besar responden tidak bekerja yaitu sebesar 58,97\%.

Tabel 1. Distribusi Frekuensi Karakteristik Responden di RW 8 Kelurahan Wonokusumo Tahun 2018

\begin{tabular}{lrc}
\hline \multirow{2}{*}{ Karakteristik } & \multicolumn{2}{c}{ Responden } \\
\cline { 2 - 3 } & $\mathbf{F}$ & $\%$ \\
\hline Umur & & \\
17 - 30 tahun & 20 & 51,28 \\
31 - 44 tahun & 15 & 38,46 \\
45 - 58 tahun & 4 & 10,26 \\
\hline Pendidikan & & \\
Tinggi & 1 & 2,57 \\
Menengah & 8 & 20,51 \\
Rendah & 30 & 76,92 \\
\hline Pekerjaan & & \\
Bekerja & 16 & 41,03 \\
Tidak Bekerja & 23 & 58,97 \\
\hline
\end{tabular}

Status Kelengkapan Imunisasi Dasar

Tabel 2. Status Imunisasi Dasar di RW 8 Kelurahan Wonokusumo Tahun 2018

\begin{tabular}{lcc}
\hline \multicolumn{1}{c}{ Status Imunisasi } & $\mathbf{n}$ & $\%$ \\
\hline Lengkap & 30 & 76,92 \\
Tidak Lengkap & 9 & 23,08 \\
Jumlah & 39 & 100 \\
\hline
\end{tabular}

Status kelengkapan imunisasi dasar terbagi menjadi 2, yaitu lengkap dan tidak lengkap. Seorang bayi dikatakan memiliki status imunisasi dasar lengkap jika telah menerima 5 jenis imunisasi dasar sebanyak 11 kali, yaitu imunisasi HB 01 kali, BCG 1 kali, Polio 4 kali, DPT-HB-Hib 3 kali dan campak 1 kali. Saat ibu bayi tidak menerima imunisasi sebanyak 11 kali, maka status imunisasi dasar bayi tersebut tidak lengkap. Berdasarkan tabel 2, diketahui bahwa sebanyak 30 batita yaitu sebesar 76,92\% memiliki status imunisasi lengkap dan 9 batita yaitu sebesar 23,08\% status imunisasinya tidak lengkap. 
Pengetahuan Ibu tentang Imunisasi Dasar

Tabel 3. Distribusi Pengetahuan Ibu dengan Status Imunisasi Dasar di Wonokusumo

\begin{tabular}{|c|c|c|c|c|c|c|}
\hline \multirow{3}{*}{ Pengetahuan } & \multicolumn{4}{|c|}{$\begin{array}{c}\text { Status Imunisasi } \\
\text { Dasar }\end{array}$} & \multirow{2}{*}{\multicolumn{2}{|c|}{ Total }} \\
\hline & \multicolumn{2}{|c|}{ Lengkap } & \multicolumn{2}{|c|}{$\begin{array}{c}\text { Tidak } \\
\text { Lengkap }\end{array}$} & & \\
\hline & $\mathrm{n}$ & $\%$ & $\mathrm{n}$ & $\%$ & $\mathrm{n}$ & $\%$ \\
\hline Baik & 19 & 48,72 & 0 & 0 & 19 & 48,72 \\
\hline Cukup & 9 & 23,08 & 3 & 7,69 & 12 & 30,77 \\
\hline Kurang & 2 & 5,13 & 6 & 15,38 & 8 & 20,51 \\
\hline Total & 30 & 76,93 & 9 & 23,07 & 39 & 100 \\
\hline
\end{tabular}

$P$ value $=0,001$

Penilaian terhadap pengetahuan dibagi ke dalam tiga kategori yaitu baik, cukup dan kurang. Berdasarkan tabel 3, diketahui bahwa sebagian besar responden memiliki tingkat pengetahuan baik tentang imunisasi dasar sebanyak 19 responden $(48,72 \%)$, tingkat pengetahuan cukup sebanyak 12 responden $(30,77 \%)$ dan tingkat pengetahuan kurang sebanyak 8 responden $(20,51 \%)$.

Hasil uji Fisher's Exact menunjukkan bahwa nilai $p=0,001<0,05$ maka $\mathrm{Ho}$ diterima sehingga terdapat hubungan antara pengetahuan ibu dengan kelengkapan status imunisasi dasar pada batita di RW 8 Kelurahan Wonokusumo.

\section{Sikap Ibu tentang Imunisasi Dasar}

Penilaian kategori sikap dibagi ke dalam 2 kategori yaitu positif dan negatif. Sikap positif jika nilai $\mathrm{T}>$ mean $\mathrm{T}$ dan sikap negatif jika $\mathrm{T} \leq$ mean $\mathrm{T}$. Berdasarkan tabel 4, diketahui bahwa masih adanya responden yang memiliki sikap negatif tentang imunisasi dasar pada batita dengan jumlah 7 responden (17,95\%). Nilai $p=0,001<0,05$ diperoleh melalui uji Chi Square yang berarti Ho diterima, sehingga terdapat hubungan antara sikap dengan kelengkapan status imunisasi dasar di RW 8 Kelurahan Wonokusumo.

\section{Persepsi Ibu tentang Imunisasi Dasar}

Penilaian kategori persepsi dibagi ke dalam 2 kategori yaitu positif dan negatif. Persepsi positif jika nilai $\mathrm{T}>$ mean $\mathrm{T}$ dan persepsi negatif jika $\mathrm{T} \leq$ mean $\mathrm{T}$.
Berdasarkan tabel 5, diketahui bahwa sebanyak 8 ibu $(20,51 \%)$ masih memiliki persepsi negatif terhadap imunisasi. Nilai $p=0,001<0,05$ diperoleh melalui uji Chi square yang berarti bahwa Ho diterima, sehingga terdapat hubungan antara persepsi ibu dengan kelengkapan status imunisasi dasar di RW 8 Kelurahan Wonokusumo.

Tabel 4. Distribusi Sikap Ibu dengan Status Imunisasi Dasar di Wonokusumo

\begin{tabular}{|c|c|c|c|c|c|c|}
\hline \multirow{3}{*}{ Sikap } & \multicolumn{4}{|c|}{$\begin{array}{c}\text { Status Imunisasi } \\
\text { Dasar }\end{array}$} & \multirow{2}{*}{\multicolumn{2}{|c|}{ Total }} \\
\hline & \multicolumn{2}{|c|}{ Lengkap } & \multicolumn{2}{|c|}{$\begin{array}{c}\text { Tidak } \\
\text { Lengkap }\end{array}$} & & \\
\hline & $\mathrm{n}$ & $\%$ & $\mathrm{n}$ & $\%$ & $\mathrm{n}$ & $\%$ \\
\hline Positif & 29 & 74,36 & 3 & 7,69 & 32 & 82,05 \\
\hline Negatif & 1 & 2,57 & 6 & 15,38 & 7 & 17,95 \\
\hline Total & 30 & 76,93 & 9 & 23,07 & 39 & 100 \\
\hline
\end{tabular}

$P$ value $=0,001$

Tabel 5. Distribusi Persepsi Ibu dengan Status Imunisasi Dasar di Wonokusumo

\begin{tabular}{|c|c|c|c|c|c|c|}
\hline \multirow{3}{*}{ Persepsi } & \multicolumn{4}{|c|}{$\begin{array}{c}\text { Status Imunisasi } \\
\text { Dasar }\end{array}$} & \multirow{2}{*}{\multicolumn{2}{|c|}{ Total }} \\
\hline & \multicolumn{2}{|c|}{ Lengkap } & \multicolumn{2}{|c|}{$\begin{array}{c}\text { Tidak } \\
\text { Lengkap }\end{array}$} & & \\
\hline & $\mathrm{n}$ & $\%$ & $n$ & $\%$ & $\mathrm{n}$ & $\%$ \\
\hline Positif & 28 & 71,80 & 3 & 7,69 & 31 & 79,49 \\
\hline Negatif & 2 & 5,13 & 6 & 15,38 & 8 & 20,51 \\
\hline Total & 30 & 76,93 & 9 & 23,07 & 39 & 100 \\
\hline
\end{tabular}

\section{Karakteristik Ibu}

Saat penelitian diketahui bahwa jumlah responden berdasarkan umur yang paling banyak adalah umur 17-30 tahun yaitu sebesar $51,28 \%$ dan yang paling sedikit adalah umur 45-58 tahun yaitu sebesar $10,26 \%$. Pengertian umur dari Hoetomo (2011) adalah lama waktu hidup atau ada (sejak dilahirkan atau diadakan). Usia seseorang diukur berdasarkan lama waktu seseorang dilihat dari segi kronologis, perkembangan anatomi tubuh dan fisiologi yang terjadi pada setiap individu (Nuswantari, 2008).

Hasil penelitian juga menunjukkan bahwa tingkat pendidikan paling banyak adalah tingkat pendidikan rendah sebanyak $50 \%$. Cara berpikir seseorang mengenai pengetahuan, sikap dan perilaku ditentukan 
oleh pendidikan yang cukup sehingga dapat dengan mudah termotivasi dalam hal pengembangan wawasan seseorang tersebut. Pendidikan merupakan proses belajar seseorang yang mengajarkan seseorang untuk dapat berpikir secara obyektif dan memberikan kemampuan kepada seseorang untuk menilai budaya di dalam masyarakat dapat diterima dan dapat mengubah tingkah laku seseorang (Sciartino, 2009).

Hasil penelitian sebagian besar responden tidak bekerja yaitu sebesar $58,97 \%$. Waktu yang lebih banyak dimiliki oleh ibu yang tidak bekerja dan lebih banyak pula menghabiskan waktu bersama anak, sehingga pola makan anak dapat diatur sehingga anak-anak bisa mengonsumsi makanan yang sehat dan bergizi. Selain itu, mereka juga dapat memberikan pendidikan kepada anak, sehingga anak bisa berkembang secara lebih baik dalam hal bahasa dan pencapaian prestasi akademik. Sebaliknya, ibu yang bekerja tidak memiliki banyak waktu untuk bisa bersama dengan anak mereka. Akan tetapi, meskipun ibu yang bekerja tidak memiliki banyak waktu bersama anak, hal tersebut tidak dapat dijadikan sebagai patokan bahwa posisi ibu yang bekerja selalu lebih buruk dari pada ibu yang tidak bekerja. Hal ini dikarenakan kebanyakan waktu yang mereka miliki semata-mata untuk membersihkan dan mengurus rumah.

\section{Status Kelengkapan Imunisasi Dasar}

Status imunisasi adalah suatu kriteria imunisasi berdasarkan kelengkapan pemberian imunisasi yang dianjurkan. Status imunisasi lengkap bila semua jenis imunisasi dasar diberikan dan tidak lengkap bila ada salah satu imunisasi dasar tidak diberikan. Status kelengkapan imunisasi dasar bayi terbagi menjadi 2, yaitu lengkap dan tidak lengkap. Seorang bayi dikatakan memiliki status imunisasi dasar lengkap jika telah menerima 5 jenis imunisasi dasar sebanyak $11 \mathrm{kali}$, yaitu imunisasi HB 01 kali, BCG 1 kali, Polio 4 kali, DPTHB-Hib 3 kali dan campak 1 kali. Imunisasi campak merupakan imunisasi yang diberikan terakhir dan dapat digunakan sebagai penilaian kelengkapan status imunisasi dasar dengan harapan imunisasi yang sebelumnya sudah diberikan dengan lengkap (Mulyani \& Rinawati, 2013).

Hasil penelitian diketahui bahwa sebanyak 30 anak yaitu sebesar $76,92 \%$ memiliki status imunisasi lengkap dan 9 anak yaitu sebesar $23,08 \%$ status imunisasinya tidak lengkap. Menurut Ibrahim (1991 dalam Rahayu, 2014), imunisasi dasar yang dilakukan secara teratur sesuai jadwal dan frekuensi imunisasi dapat mengurangi kesakitan dan kematian balita hingga 8095\%. Berbeda halnya dengan imunisasi dasar tidak lengkap yang hanya memberi perlindungan $25-40 \%$, sedangkan bayi yang tidak diimunisasi tentu memiliki kekebalan yang lebih rendah.

Menurut data Riset Kesehatan Dasar (2013) menyebutkan beberapa alasan anak tidak diimunisasi, karena tempat imunisasi yang jauh dan tidak tahu tempat imunisasi serta kesibukan orang tua. Orang tua yang takut anaknya akan mengalami panas juga menjadi alasan tidak diimunisasi, sehingga keluarga tidak mengizinkan (Depkes RI, 2014). Alasan lain anak tidak mendapatkan imunisasi yang lengkap menurut Dewi et al. (2014) yaitu karena kurangnya informasi tentang imunisasi yang diterima oleh ibu, motivasi ibu yang kurang serta keadaan lingkungan. Kurangnya pengetahuan ibu tentang imunisasi dan manfaatnya, serta adanya isu yang tidak baik tentang imunisasi, sehingga menimbulkan kurangnya kepercayaan masyarakat tentang manfaat imunisasi. Bayi yang telah diimunisasi memiliki kemungkinan untuk tertular penyakit tertentu tetapi jauh lebih ringan dibandingkan dengan bayi yang tidak mendapatkan imunisasi.

\section{Pengetahuan Ibu tentang Imunisasi Dasar}

Pengetahuan merupakan pemahaman mengenai sejumlah informasi dan pengenalan secara obyektif terhadap benda - benda atau sesuatu hal. Pengetahuan juga dapat diperoleh melalui pengalaman yang dialami seseorang dan melalui hasil belajar seseorang secara formal maupun informal (Toruntju, 2013). Pengetahuan dapat dipengaruhi oleh rasa takut sehingga mencari tahu lebih dalam tentang hal tersebut. Semakin dalam pengetahuan yang diperoleh, maka ibu akan semakin bijaksana dalam berpersepsi terhadap suatu hal dan mengambil keputusan. Perilaku 
yang dilandaskan oleh pengetahuan akan bersifat lama atau terus-menerus dibandingkan perilaku yang dilandasi oleh keterpaksaan.

Hasil penelitian menunjukkan sebanyak 19 responden yaitu sebesar $48,72 \%$ memiliki pengetahuan yang baik dan sebanyak 8 responden yaitu sebesar 20,51\% memiliki pengetahuan dengan kategori kurang tentang imunisasi dasar. Pengetahuan ibu yang kurang akan berdampak pada status kelengkapan imunisasi dasar pada batita sebagaimana hasil penelitian Puspita (2018) yang menyatakan bahwa semakin rendah pengetahuan ibu, maka semakin banyak berkontribusi terhadap ketidaklengkapan imunisasi. Buruknya pengetahuan tentang imunisasi juga berkaitan dengan peran ibu dalam melengkapi imunisasi bayinya. Penelitian Dewi, dkk (2013) menyatakan bahwa ibu dengan pengetahuan rendah cenderung tidak memberikan imunisasi dasar lengkap dibandingkan ibu yang berpengetahuan tinggi.

\section{Sikap Ibu tentang Imunisasi Dasar}

Sikap merupakan suatu reaksi seseorang yang masih tertutup terhadap suatu rangsangan dimana faktor pendapat dan emosi sudah terlibat di dalamnya. Perwujudan sikap hanya dapat ditafsirkan melalui perilaku yang tertutup dan tidak bisa dilihat langsung. Sikap merupakan keseluruhan dari kecenderungan perasaan, asumsi, ide, keyakinan manusia tentang topik tertentu. Tidak hanya ditentukan oleh aspek internal individu, sikap juga melibatkan nilai-nilai yang dibawa dari kelompoknya (Notoatmodjo, 2012).

Hasil penelitian diketahui bahwa masih adanya responden yang memiliki sikap negatif tentang imunisasi dasar pada balita dengan jumlah 7 responden (17,95\%). Sikap ibu terhadap imunisasi akan berdampak pada kelengkapan imunisasi dasar lengkap pada batita. Sebagaimana hasil penelitian yang dilakukan oleh Prisilin, R., Dyer, A., Blakely, C.H. \& Johnson (2011) yang menyatakan bahwa sikap yang positif berkontribusi pada tingkat imunisasi yang lebih tinggi. Hal ini didukung pula oleh penelitian Octaviani (2015) yang menunjukkan bahwa ada hubungan bermakna antara sikap positif responden terhadap status imunisasi dasar.

\section{Persepsi Ibu tentang Imunisasi Dasar}

Notoatmodjo (2010) mendefinisikan persepsi sebagai suatu penafsiran dan penarikan kesimpulan tentang informasi yang didapatkan berdasarkan pengalaman terhadap peristiwa atau suatu objek yang diawali melalui proses penginderaan.

Hasil penelitian menunjukkan bahwa sebanyak 8 ibu $(20,51 \%)$ masih memiliki persepsi negatif terhadap imunisasi. Persepsi negatif merupakan keadaan seseorang yang menolak terhadap suatu obyek tertentu dan memandang bahwa obyek tersebut tidak sesuai dengan pribadinya. Persepsi seseorang dapat dipengaruhi oleh faktor internal dan faktor eksternal. Perasaan, keinginan, harapan, sikap dan kepribadian individu, prasangka, perhatian (fokus), proses belajar, keadaan fisik, kebutuhan dan minat termasuk ke dalam faktor internal. Sedangkan informasi yang didapat, pengetahuan, kebutuhan, latar belakang keluarga, ukuran, intensitas, dan hal-hal yang baru termasuk ke dalam faktor eksternal. Menurut ibu di RW 8 Kelurahan Wonokusumo, imunisasi masih dianggap tidak perlu karena keyakinan atau sosiobudaya. Selain itu ibu juga masih memiliki kesalahpahaman tentang efek samping imunisasi.

Hubungan antara Pengetahuan Ibu dengan Status Imunisasi Dasar di Wonokusumo

Nilai $p=0,001<0,05$ didapatkan dari hasil uji Fisher's Exact yang berarti Ho diterima. Oleh karena itu dapat ditarik kesimpulan bahwa terdapat hubungan antara pengetahuan ibu dengan kelengkapan status imunisasi dasar di RW 8 Kelurahan Wonokusumo

Tingkat pengetahuan dapat diperoleh berdasarkan tingkat pendidikan formal baik formal maupun informal, pengalaman hidup maupun informasi yang didapat dari media massa. Pengetahuan lebih bersifat pengenalan terhadap sesuatu benda atau hal tertentu secara obyektif. Selain itu pengetahuan juga berasal dari pengalaman tertentu yang pernah dialami oleh seseorang dan yang diperoleh dari hasil belajar secara formal maupun informal (Toruntju, 2013).

Pemberian imunisasi dasar pada batita berkaitan erat dengan pengetahuan ibu mengenai imunisasi dasar dengan 
bagaimana ibu memahami arti dan manfaat yang didapat dari pelayanan kesehatan seperti posyandu maupun puskesmas. Selaras dengan hasil penelitian Rahmawati (2013) yang menyatakan tingkat pengetahuan ibu tidak berpengaruh terhadap status kelengkapan imunisasi dasar bayi, namun tingkat pengetahuan memiliki hubungan yang bermakna dengan tingkat pengetahuan kurang berisiko 8,7 kali menyebabkan ketidaklengkapan imunisasi dasar bayi. Sejalan juga dengan penelitian Harmasdiani (2015), di Probolinggo yang menunjukkan bahwa pengetahuan ibu yang rendah memiliki risiko 21 kali lebih tidak patuh untuk dating ke posyandu dan memberikan imunisasi disbanding ibu dengan pengetahuan tinggi.

Selain hal tersebut adanya pengetahuan ibu akan pentingnya imunisasi dasar pada balita dan akibat yang ditimbulkan apabila ibu tidak memberikan anaknya imunisasi dasar yang lengkap terhadap penyakit-penyakit seperti TBC, polio, campak, dan DPT. Ibu yang memiliki tingkat pengetahuan baik mengenai pemberian imunisasi dasar yang lengkap pada balita disebabkan karena latar belakang pendidikan ibu baik secara formal maupun informal.

Hasil analisis dalam penelitian ini, dimana masih adanya responden yang memiliki tingkat pengetahuan yang kurang terhadap perilaku untuk memberikan imunisasi dasar yang lengkap pada balitanya yaitu sebesar $20,51 \%$, ibu yang memiliki tingkat pengetahuan baik lebih cenderung memiliki perilaku untuk memberikan imunisasi dasar yang lengkap pada balitanya sebesar 30,77 \%. Hasil dari penelitian ini sesuai dengan Notoatmodjo (2010), dimana pengetahuan merupakan salah satu faktor yang berpengaruh terhadap sikap, persepsi, dan juga tingkat kepercayaan untuk lebih memotivasi seseorang untuk bertindak.

Penelitian Josiman (2013) didapatkan bahwa pengetahuan ibu mempunyai tingkat keeratan dengan kelengkapan imunisasi yang tergolong rendah. Pengetahuan juga dapat memudahkan atau mengimbangi seseorang maupun sekelompok orang untuk berubah dan pengetahuan tersebut dapat diperoleh melalui pengalaman dan belajar, Oleh karena itu ketika seseorang akan melakukan suatu tindakan maka seseorang harus memiliki pengetahuan yang cukup maupun baik untuk mampu menentukan tindakan apa yang akan dilakukan.

Keinginan ibu untuk melengkapi status kelengkapan imunisasi dasar pada balitanya tidak terlepas dari pengetahuan yang dimiliki ibu tersebut memahami pentingnya imunisasi dasar, sehingga diharapkan dari tingkat pengetahuan ibu tersebut akan muncul sikap dan perilaku untuk lebih memanfaatkan fasilitas pelayanan kesehatan yang tersedia dalam mendapatkan pelayanan imunisasi. Responden yang memiliki tingkat pengetahuan yang kurang disebabkan oleh tingkat pendidikan ibu yang rendah dan juga kurangnya pemahaman informasi tentang imunisasi dasar pada balita. Hal tersebut terlihat dari hasil pengisian kuesioner dimana responden masih banyak yang menjawab kurang sesuai dengan pertanyaan-pertanyaan pada kuesioner tersebut dan itu berarti bahwa ibu-ibu tersebut tidak tahu dan tidak mengerti tentang pentingnya imunisasi dasar pada batita terutama ibu-ibu yang berada di RW 8 Kelurahan Wonokusumo.

\section{Hubungan antara Sikap Ibu dengan Status Imunisasi Dasar di Wonokusumo}

Nilai $p=0,001<0,05$ didapatkan dari hasil uji Chi square yang berarti Ho diterima. Oleh karena itu dapat disimpulkan bahwa sikap ibu berhubungan dengan kelengkapan status imunisasi dasar di RW 8 Kelurahan Wonokusumo

Hasil penelitian ini didukung oleh penelitian yang dilakukan Paridawati (2013) bahwa ada hubungan antara sikap positif ibu dengan pemberian imunisasi dasar. Sama halnya dengan penelitian Octaviani (2015) bahwa ada hubungan antara sikap positif responden dengan status imunisasi dasar.

Notoatmodjo (2010) menyatakan bahwa sikap merupakan suatu tindakan, namun masih berupa reaksi tertutup dari seseorang terhadap objek. Teori Alport menyebutkan ada 3 komponen pembentukan sikap, yaitu keyakinan, emosional atau evaluasi terhadap objek yang cenderung untuk melakukan suatu tindakan. Sikap ibu ditinjau dari ketiga komponen tersebut menjadi pembeda yang nyata dalam penelitian ini. Mayoritas ibu tidak mau mengimunisasikan bayinya secara lengkap 
memiliki keyakinan bahwa imunisasi hanya membuat bayi menjadi sakit dan menilai tidak berpengaruh terhadap peningkatan kesehatan bayi. Sedangkan ibu yang memiliki sikap positif menilai bahwa manfaat imunisasi lebih banyak daripada efek samping yang ditimbulkan cenderung untuk mengimunisasikan bayi secara lengkap. Hasil ini sesuai dengan penelitian

Menurut hasil penelitian diperoleh bahwa sebagian besar sikap ibu terkait imunisasi dasar lengkap sudah baik. Bagitu juga penelitian yang dilakukan oleh Tampemawa (2015) bahwa antara sikap ibu dengan status imunisasi anak usia 12-24 bulan terdapat hubungan yang bermakna. Terbukti bahwa ibu yang tidak mengimunisasikan bayinya secara lengkap mayoritas memiliki sikap yang negatif. Pernyataan ini sesuai dengan yang dijelaskan oleh Notoatmodjo (2010), bahwa perilaku baru pada orang dewasa mulai dibentuk pada domain pengetahuan dimana stimulus atau objek diketahui terlebih dahulu oleh subjek. Hal ini juga didukung penelitian Paridawati (2013) yang menyebutkan adanya hubungan yang signifikan mengenai sikap terhadap pemberian imunisasi dasar.

Suatu bentuk respons yang baru dapat timbul dalam sikap terhadap objek yang diketahuinya dan akhirnya respons tersebut akan timbul secara lebih jauh yang berupa suatu tindakan. Beberapa ibu yang memiliki sikap yang positif kemungkinan adanya faktor lain selain tingkat pendidikan dan pengetahuan misalnya, ibu yang membawa anaknya ke posyandu karena melihat tetangga datang ke posyandu sehingga bisa ikutan kumpul-kumpul, atau karena diajak oleh tetangga dan juga karena mendengar ada pengumuman diadakannya posyandu atau kegiatan kesehatan yang lainnya. Disamping itu juga ibu yang memiliki sikap negatif terhadap pelayanan imunisasi dasar pada balita disebabkan karena faktor budaya dan juga salahnya informasi yang didapat tentang pemberian imunisasi pada balita dapat menimbulkan anak menjadi sakit bahkan adanya meninggal setelah diberikan imunisasi.

Hubungan Antara Persepsi Ibu dengan Status Imunisasi Dasar di Wonokusumo

Nilai $p=0,001<0,05$ didapatkan dari hasil uji Chi square yang berarti Ho diterima sehingga kesimpulannya yaitu terdapat hubungan antara persepsi ibu dengan kelengkapan status imunisasi dasar di RW 8 Kelurahan Wonokusumo.

Persepsi merupakan proses terintegrasi meliputi pengorganisasian stimulus yang diperoleh dari penginderaan oleh individu, dalam penelitian ini adalah ibu. Persepsi dipengaruhi oleh faktor internal, oleh karenanya stimulus yang sama dapat dipersepsikan berbeda oleh tiap individu (Notoatmodjo, 2010). Pada dasarnya persepsi dapat diasosiasikan dengan pendapat, opini atau sikap (attitude). Mar'at (1982, dalam Cahyanti, 2011) menyebutkan persepsi sebagai aspek kognitif dari sikap. Mengingat bahwa persepsi merupakan aspek kognitif dari sikap, maka untuk mengungkap atau mengukur persepsi dapat digunakan instrumen pengungkapan sikap. Mar'at mengemukakan tiga pendekatan untuk mengungkap sikap yaitu wawancara langsung, observasi dan pernyataan sikap.

Hasil penelitian ini menunjukkan bahwa persepsi ibu ada hubungan dengan status kelengkapan imunisasi dasar pada batita. Ibu yang memiliki persepsi positif akan berdampak pada status kelengkapan imunisasi dasar pada batita, sebaliknya ibu yang berpersepsi negatif maka berdampak pada ketidaklengkapan status imunisasi dasar pada batita. Hal ini selaras dengan penelitian As ad, dkk (2016) yang menyebutkan bahwa persepsi yang tinggi akan mendorong suatu motivasi yang baik untuk melakukan suatu kegiatan, salah satunya seorang ibu yang baru saja melahirkan membutuhkan persepsi yang tinggi baik dari faktor internal dan eksternal untuk memotivasinya agar melakukan suatu kegiatan tertentu dalam mencapai tujuan dengan cara memberi imunisasi dasar lengkap pada bayinya.

Menurut Ajzen (2005) dikutip dari Meilisha, implikasi motivasional pada niat seseorang dimiliki oleh kendali perilaku yang ditunjukkan dengan seseorang yang tidak memiliki sumber daya atau kesempatan untuk menampilkan perilaku, maka seseorang tersebut cenderung memiliki niat yang tidak begitu kuat walaupun sikap yang positif dimiliki olehnya dan dukungan dari orang-orang terdekat terhadap perilakunya. Persepsi dalam 
mengendalikan perilaku terdiri dari control belief dan perceived belief.

Control belief merupakan keyakinan bahwa individu pernah melaksanakan/ tidak perilaku tertentu, individu melakukan estimasi atau kemampuan dirinya (control belief) apakah dia punya kemampuan atau tidak mempunyai kemampuan untuk melaksanakan perilaku itu. Perceived belief adanya persepsi individu terhadap kekuatan/kemampuan faktor kendali juga mempengaruhi individu dalam menentukan niat untuk melakukan/ tidak melakukan perilaku kepatuhan tersebut. Control belief ibu yang menjadi responden di RW 8 Kelurahan Wonokusumo dipengaruhi oleh faktor pendidikan ibu. Faktor pendidikan yang rendah menyebakan ibu memiliki pengetahuan yang kurang tentang imunisasi dasar. Dari Control belief tersebut masih terdapat perceived belief/kekuatan dalam mengendalikan, yaitu dimana dari beberapa faktor diatas ibu masih mempunyai suatu tanggung jawab dalam hal memenuhi kelengkapan imunisasi dasar bayinya. Apabila persepsi para ibu baik sehingga akan terlaksana juga kelengkapan dalam memenuhi imunisasi dasar pada bayi mereka, demikian juga sebaliknya apabila persepsi para ibu jelek maka kelengkapan imunisasi dasar pada batita tidak akan tercapai.

\section{SIMPULAN}

Hasil penelitian dan data yang menunjukkan bahwa hasil uji statistik terdapat adanya hubungan antara pengetahuan, sikap, dan persepsi ibu dengan status imunisasi dasar di RW 8 Kelurahan Wonokusumo.

\section{DAFTAR PUSTAKA}

As ad, dkk. 2016. Hubungan Persepsi Dengan Motivasi Ibu Muda Primipara Dalam Melakukan Imunisasi Dasar Lengkap Pada Bayi Di Desa Ambunten Barat Kecamatan Ambunten Kabupaten Sumenep. Skripsi. Jember : Universitas Muhammadiyah Jember. http: / / digilib.unmuhjember. ac.id [Sitasi 5 April 2018].

Daman, Nur Jelita Amin. 2016. Faktor Yang Mempengaruhi Status Kelengkapan Imunisasi Dasar Bayi di Bangkalan Tahun 2016. Skripsi. Surabaya: Fakultas
Kesehatan Masyarakat Universitas Airlangga.

Dewi A. P., Darwin, E., \& Edison. 2014. Hubungan Tingkat Pengetahuan Ibu Dengan Pemberian Imunisasi Dasar Lengkap Pada Bayi Di Kelurahan Parupuk Tabing Wilayah Kerja Puskesmas Lubuk Buaya Kota Padang Tahun 2013. Jurnal Kesehatan Andalas. 3(2), 114-118. http://jurnal.fk.unand.ac.id [Sitasi 8 April 2018].

Dinas Kesehatan Kota Surabaya. 2016. Profil Kesehatan Tahun 2016..

Dinas Kesehatan Kota Surabaya. 2015. Profil Kesehatan Tahun 2015.

Dinas Kesehatan Provinsi Jawa Timur. 2016. Profil Kesehatan Provinsi Jawa Timur Tahun 2016.

Febriastuti, Niken, dkk. 2013. Kepatuhan Orang Tua Dalam Pemberian Kelengkapan Imunisasi Dasar Pada Bayi 4-11 Bulan. Pediomaternal Nursing Journal, Vol 2 No. 2. Surabaya : Program Studi S1 Pendidikan Ners Fakultas Keperawatan Universitas Airlangga. http://ejournal. unair.ac.id [Sitasi 11 April 2018].

Hengkengbala, Lefrin, dkk. 2013. Hubungan Antara Pengetahuan Dan Sikap Ibu Tentang Imunisasi Dengan Status Imunisasi Anak Balita Di Kampung Farusi Distrik Swandiwe Kabupaten Biak Numfor Provinsi Papua. Jurnal Kesehatan Masyarakat Universitas Sam Ratulangi, 2(1): 42-51 2013. Fakultas Kesehatan Masyarakat Universitas Sam Ratulangi Manado.http://jkesmasfkm.unsrat.ac.id [Sitasi 7 April 2018].

Kementerian Kesehatan Republik Indonesia. 2016. Profil Kesehatan Indonesia Tahun 2016. Jakarta : Kementerian Kesehatan RI.

Notoadmodjo, Soekidjo. 2010. Promosi Kesehatan Teori Dan Aplikasi. Jakarta: Rineka Cipta.

Notoadmodjo, Soekidjo. 2012. Ilmu Perilaku Kesehatan. Jakarta: Rineka Cipta.

Noviar, Indra. 2018. Upaya Peningkatan Cakupan Imunisasi Dasar Lengkap Melalui Analisis Costumer Value di Wilayah Kerja Puskesmas Kota Surabaya. Thesis. Surabaya : Fakultas Kesehatan Masyarakat Universitas Airlangga.

Paridawati., Rachman, W.A., Fajarwati, I. 2013. Faktor Yang Berhubungan Dengan Tindakan Ibu Dalam Pemberian Imunisasi Dasar Pada Bayi Di Wilayah Kerja 
Puskesmas Bajeng Kecamatan Bajeng Kabupaten Gowa. Skripsi. Makassar : FKM Universitas Hasanuddin Makassar. http: / / repository.unhas.ac.id [Sitasi 12 April 2018].

Puri, Yessica Eka. 2014. Pengaruh Persepsi lbu Tentang Imunisasi Ditinjau dengan Health Belief Model Terhadap Kelengkapan Status Imunisasi. Thesis. Surakarta : Universitas Sebelas Maret. http:// digilib.uns.ac.id [Sitasi 7 April 2018].

Puspita, Ndaru. 2018. Analisis Faktor Penyebab Ketidaklengkapan Imunisasi dasar Pada Bayi. Skripsi. Surabaya : Fakultas Kesehatan Masyarakat Universitas Airlangga.

Riset Kesehatan Dasar. 2013. Riset Kesehatan Dasar, Badan Penelitian dan Pengembangan Kesehatan Kementerian Kesehatan RI Tahun 2013.

Riyanto, Dwi Agung. 2013. Hubungan Pengetahuan Dan Sikap Ibu Tentang Imunisasi Dasar Dengan Perilaku Pelaksanaan Imunisasi Dasar Pada Balita Di Kampung Cantilan Kelurahan Kagungan Kecamatan Kasemen Kota Serang Tahun 2013. Banten: Sekolah Tinggi Ilmu Kesehatan Faletehan.

Sciortino, Rosalia. 2009. Menuju Kesehatan Madani. Yogyakarta: Gadjah Mada University Press.

Simbolon, Lucia Nauli. 2013. Korelasi Pengetahuan, Sikap dan Persepsi Bidan Terhadap Perilaku Pemberian Vaksin Hepatitis B Saat Lahir. Yogyakarta : Departemen Ilmu Kesehatan Anak Fakultas Kedokteran Universitas Gadjah Mada RSUP Dr. Sardjito. http: / / repository.ugm.ac.id [Sitasi 1 April 2018]
Toruntju Sa. 2013. Faktor Sosial Ekonomi Yang Berhubungan Dengan Ibu di daerah Endemik Gaky. Thesis. Yogyakarta: UGM

Umaroh, Siti. 2014. Hubungan Antara Pengetahuan Dan Sikap Ibu Dengan Kelengkapan Imunisasi Dasar Di Wilayah Kerja Puskesmas Kartasura Kabupaten Sukoharjo. Naskah Publikasi. Surakarta : Program Studi Kesehatan Masyarakat Fakultas IImu Kesehatan Universitas Muhammadiyah Surakarta. http:// eprints.ums.ac.id [Sitasi 1 April 2018]

Wardani, Dian Palupi Kusuma, dkk. 2013. Hubungan Persepsi dengan Perilaku Ibu Membawa Balita ke Posyandu. Jurnal Keperawatan Padjajaran, 3(1): 1-10 2015. Fakultas Keperawatan Universitas Padjadjaran. http://jkp.fkep.unpad. ac.id [Sitasi 1 April 2018]

Wulandari, Dewi, Dwidiyanti, Meidiana. 2017. Pengetahuan dan Persepsi Ibu yang Menolak Pemberian Imunisasi Dasar Balita. Indonesian Journal On Medical Science - Volume 4 No 1. http: / / ejournal. ijmsbm.org [Sitasi 2 April 2018]

Yuda, Alfiyan Dharma, Nurmala, Ira. 2017. Hubungan Karakteristik, Pengetahuan, Sikap Dan Tindakan Ibu Terhadap Kepatuhan Imunisasi Di Wonokusumo, Surabaya. Jurnal Berkala Epidemiologi, Volume 6 Nomor 1. http://e-journal. unair.ac.id [Sitasi 2 April 2018]

Yundri, dkk. 2017. Faktor Yang Berhubungan Dengan Ketidaklengkapan Status Imunisasi Anak Di Puskesmas Kuala Tungkal II. Jurnal Berkala Epidemiologi, Volume 5 Nomor 3. http://e-journal. unair.ac.id [Sitasi 2 April 2018] 